\title{
NOTE
}

\section{Phaeocystis colony mucus components and the importance of calcium ions for colony stability}

\author{
W. H. M. van Boekel \\ Department of Marine Biology, University of Groningen, PO Box 14, 9750 AA Haren, The Netherlands
}

\begin{abstract}
The composition and properties of Phaeocystis colony mucus are still largely obscure. In this study some components of the mucus were identified using a specific staining technique and the role of $\mathrm{Ca}^{2+}$ and other cations as binding agent was investigated. In addition, the effect of $\mathrm{Ca}^{2+}$ concentration on colony formation in batch cultures was studied. Colonies of Phaeocystis sp. were stained with alcian blue at 2 different $\mathrm{pH}$ values. This revealed that the colony mucus contained both carboxylated and sulfated polymers. Incubation of colonies in medium lacking one or more cations showed that calcium and magnesium ions were essential for the gelling of colony mucus, while potassium ions had no influence. The percentage colony cells formed by Phaeocystis in batch cultures was reduced in medium with calcium concentrations below $2.5 \mathrm{mmol} \mathrm{l}^{-1}$. No colonies were formed in medium with calcium concentrations below $1.5 \mathrm{mmol}^{-1}$ Growth rate was not dependent on calcium concentration. It is suggested that under natural conditions Phaeocystis colony firmness and morphology might depend on the composition of mucus polymers.
\end{abstract}

In the marine environment mucus production is known to occur in bacteria (Decho 1990), macroalgae (Boney 1981) and several groups of microalgae such as diatoms (Decho 1990), green algae (Crayton 1982) and the Prymnesiophyceae (Painter 1983). The composition of mucus produced by these groups is often rather complex, consisting of heteropolymeric chains containing a wide variety of simple sugars, aminosugars, uronic acids, sulfated or phosphated sugars, amino acids, etc. The gelling capacity of mucus depends on the binding of negatively charged groups in the molecule (mostly carboxyl groups) with cations (mostly $\mathrm{Ca}^{2+}$ ). In this way ionic bridges are formed between polymer strands. The number of ionic bridges formed in a polymer depends on the number of anionic groups and the steric arrangement of these groups in the molecule (Kohn et al. 1968). Colony-forming algae such as the Volvocaceae produce mucus with large amounts of carboxyl and sulfate groups (Crayton 1982).
The alga Phaeocystis sp. is an important component of the phytoplankton of several marine ecosystems, such as the North Sea and the Arctic and Antarctic oceans (Barnard et al. 1984, Cadée \& Hegeman 1986, Palmisano et al. 1986, Lancelot et al. 1987, Gibson et al. 1990, Wassmann et al. 1990). Phaeocystis forms colonies consisting of mucus in which cells are randomly distributed. The colonies are spherical or elongated and reach sizes of up to $5 \mathrm{~mm}$ in diameter, containing over 10000 cells (Rouseau et al. 1990). During bloom situations in the North Sea, when Phaeocystis cell number often exceeds $50 \times 10^{6} \mathrm{1}^{-1}$ (Cadée \& Hegeman 1986), colony mucus may represent $50 \%$ or more of total phytoplankton biomass (Rouseau et al. 1990). The formation of foam layers on beaches following Phaeocystis blooms (Bätje \& Michaelis 1986) suggests that the mucus is not easily decomposed, either (photo)chemically or bacterially. The composition of Phaeocystis mucus is as yet largely unknown. The research that has been done has yielded contradictory results. Guillard \& Hellebust (1971) found that the mucus of 2 Phaeocystis strains consisted of oligo- and polysaccharides of heterogeneous composition. Painter (1983) reported some preliminary results of the analysis of an impure bloom of Phaeocystis, showing that the mucus might be a very complex, soluble proteoglycan. Lancelot et al. (1991) mentioned that the mucus is a polysaccharide, mainly composed of glucose units. Knowledge of mucus composition and properties is essential for understanding the role of Phaeocystis in the ecosystem, since it may help to explain the processes of Phaeocystis colony formation and growth, as well as diffusion inside colonies, aggregation and sedimentation of colonies and the flux of mucus carbon to the microbial foodweb. This study represents a further step in elucidating the composition and properties of the colonial mucus of Phaeocystis. 
Materials and methods. All experiments were performed with axenic Phaeocystis sp. (strain K) isolated from the Dutch Wadden Sea. This strain formed globosa-type colonies (Jahnke 1989). Phaeocystis was grown in $1 \mathrm{l}$ serum bottles incubated on a rolling device at $10^{\circ} \mathrm{C}$ and a light intensity of $40 \mu \mathrm{E} \mathrm{m} \mathrm{m}^{-2} \mathrm{~s}^{-1}$ in a 14:10 L:D cycle. The artificial seawater medium described by Veldhuis \& Admiraal (1987) was used for culturing and for all experiments. The medium had nutrient concentrations of $4 \mu \mathrm{mol} \mathrm{l} \mathrm{l}^{-1} \mathrm{PO}_{4}{ }^{3-}$ and $70 \mu \mathrm{mol} 1^{-1} \mathrm{NO}_{3}^{-}$, while the $\mathrm{Ca}^{2+}$ concentration was $3.6 \mathrm{mmol} \mathrm{l}^{-1}$. Under these conditions Phaeocystis predominantly formed large colonies, suitable for the experiments described below. The presence of carboxylated and sulfated polymers in mucus of living Phaeocystis colonies was investigated with the use of alcian blue, a cationic copper phthalocyanine dye. which is specific for these poly-anionic groups (Scott et al. 1964, Ramus 1977). Differentiation between carboxylated and sulfated polysaccharides was possible since the dye binds to both types at $\mathrm{pH} \mathrm{2.5,} \mathrm{and} \mathrm{to}$ sulfated polymers only at $\mathrm{pH} 0.5$ (Crayton 1982). Alcian blue does not bind to phosphate groups at these $\mathrm{pH}$ values (Scott et al. 1964). The staining method used by Crayton (1982) was adapted for use in seawater medium. To obtain the different $\mathrm{pH}$ values in the reaction mixture $0.1 \%(\mathrm{w} / \mathrm{v})$ alcian blue was made in either $0.5 \mathrm{~N} \mathrm{HAc}$ (for $\mathrm{pH} 2.5$ ) or in $0.5 \mathrm{~N} \mathrm{HCl}$ (for $\mathrm{pH} \mathrm{0.5).} \mathrm{The}$ alcian blue stocks were prepared in a solution containing the major salts of the seawater medium used for culturing Phaeocystis in order to prevent osmotic shock of the cells during treatment. For staining of colonies the alcian blue stocks were mixed 5 parts to 2 with concentrated colony suspensions in glass tubes. The mixtures were kept at room temperature for at least $15 \mathrm{~min}$. Thereafter they were diluted 10-fold with seawater in order to make the colonies visible. Colonies were picked out with pipettes, transferred to microscope chambers and observed with an inverted microscope. Control experiments showed that alcian blue did not bind to living single cells of Phaeocystis, indicating that staining was specific for mucus. Pieces of agar gel (a polymer containing both carboxylated and sulfated groups) that were stained using the same method as for colonies showed a strong blue colour at both $\mathrm{pH}$ values, indicating that the seawater medium did not affect the staining reaction. Also, Crayton (1982) found that addition to the reaction mixture of up to $0.5 \mathrm{M} \mathrm{NaCl}$ did not affect binding of alcian blue to polymers at both $\mathrm{pH}$ values.

Since cations were expected to have an important function in the gelling of colony mucus, the effect of omission of one or more cations from the medium on colony cohesion was examined. For this purpose seawater medium was prepared in which $\mathrm{K}^{+}, \mathrm{Ca}^{2+}, \mathrm{Mg}^{2+}$, a combination of two of these, or all three were lacking. The omitted ion was replaced by $\mathrm{Na}^{+}$in order to maintain approximately the same salinity in the medium. Triplicate $5 \mathrm{ml}$ portions of these media and of complete medium (control) were distributed over sterile, translucent culturing plates containing 25 chambers each. Healthy colonies were concentrated from a Phaeocystis culture growing in standard medium and small aliquots $(0.1$ to $0.25 \mathrm{ml})$ of this concentrate were transferred to the different media in the chambers. The plates were incubated for $1 \mathrm{wk}$ at $10^{\circ} \mathrm{C}$ and low light intensity and colonies were checked regularly using inverted microscopy.

The effect of different calcium concentrations on colony formation during growth was studied in batch culture experiments. For these experiments calciumfree medium was inoculated with Phaeocystis and distributed in $200 \mathrm{ml}$ portions among several $250 \mathrm{ml}$ serum bottles. To each bottle a different amount of a $\mathrm{CaCl}_{2}$ stock solution was added, to final calcium concentrations ranging between 0.175 and $7.5 \mathrm{mmol}$ $\mathrm{Ca} \mathrm{l}^{-1}$. The bottles were incubated under standard conditions as described above. Growth and colony formation in each culture was followed in time. Cell counts were performed according to van Boekel \& Veldhuis (1990). In all experiments cultures were examined regularly for bacterial contamination using fluorescence microscopy after staining of samples with Hoechst dye no. 33258 (Paul 1982). No bacterial contamination was detected during the experiments.

Results and discussion. Treatment of Phaeocystis sp. colonies with alcian blue at $\mathrm{pH} 2.5$ resulted in a strong blue staining of the colony mucus (visible as the grey tint of the colony mucus in Fig. 1B compared with the translucent appearance of the mucus in the control colony in Fig. 1A). At pH 0.5 staining of the mucus was less intense but still evident (in Fig. $1 \mathrm{C}$ mainly visible as the darker colony membrane compared with the control). These results indicate that Phaeocystis colony mucus contains both carboxylated and sulfated polymers. Preliminary results of NMR (nuclear magnetic resonance) analysis of purified mucus from Phaeocystis cultures and field samples indicate that the mucus is of complex composition. The NMR spectra of Phaeocystis mucus show no resemblance to spectra of known algal or other polymers ( $H$. Huizing pers. comm.). This is in accordance with the results of Painter (1983), who found hemiester sulfates and residues of galacturonic acid, together with glucosamine and a number of saccharides, in extracts of a natural Phaeocystis bloom. Polymer production also occurs in other members of the class Prymnesiophyceae, to which Phaeocystis belongs. Emiliania huxleyi and Hymenomonas carterae both produce a complex glycan containing uronic acids and various 
saccharides (de Jong 1975, Painter 1983). These polymers have a strong calcium-binding capacity and are involved in coccolith formation. The polymer produced by Phaeocystis might very well resemble these polymers both in structure and in calcium-binding properties (see below)

Incubation of Phaeocystis colonies in media lacking one or more cations showed that mucus gelling depended on bivalent cations $\left(\mathrm{Ca}^{2+}, \mathrm{Mg}^{2+}\right)$. Colonies incubated in medium lacking one or both of these ions lost their shape and fell apart within $1 \mathrm{~d}$. The first sign of this disintegration process was the disappearance of what is called the colony membrane after about $4 \mathrm{~h}$. This 'membrane' (encircling the colony as visible in Fig. 1A) is probably an optical effect, caused by the difference in optical properties of colony mucus and the surrounding seawater medium. The disappearance of the membrane thus indicated the fading of the sharp border between colony mucus and medium. In medium lacking $\mathrm{K}^{+}$and in the control medium colonies remained intact and the colony membrane remained clearly visible. Omission of $\mathrm{K}^{+}$and $\mathrm{Mg}^{2+}$ caused cell death in the colonies after a short time but colony cells grew well in medium lacking $\mathrm{Ca}^{2+}$. Prolonged incubation of colonies in calcium-free medium in the culture plates resulted in the formation of lumps of cells loosely packed in mucus. These lumps could easily be dispersed by moving the culture plate. Apparently the cells still produced mucus, but the absence of calcium made colony formation impossible.

In another experiment Phaeocystis colony formation during growth was tested in batch cultures with calcium concentrations of $0.175,0.35,1.25,1.5,1.75,2.0$, $2.5,3.75,5.0$, and $7.5 \mathrm{mmol} \mathrm{Ca} \mathrm{l}{ }^{-1}$ (Table 1). In cultures with calcium concentrations of 0.35 and $1.25 \mathrm{mmol} \mathrm{l}^{-1}$ only single cells were found. Colonies were formed when the calcium concentration was $1.5 \mathrm{mmol} \mathrm{l}^{-1}$ or more. The percentage of colonized cells increased in the range of 1.5 to $2.5 \mathrm{mmol} \mathrm{Ca} \mathrm{l}^{-1}$ and remained

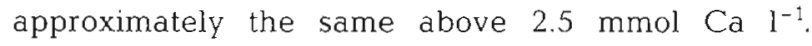
Probably, the upper limit of the percentage of colony cells was determined by the rate of transition of single cells into colony-forming cells in the cultures. Growth rates during the exponential phase were the same in

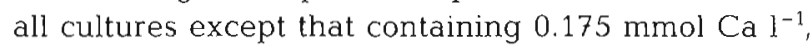
where no growth occurred. It is known that gel firmness depends on the number of ionic bridges serving as cross-links between polymeric chains (Decho 1990). It is shown here that in Phaeocystis calcium and magnesium serve as intermediates in these ionic bridges.

Fig. 1. Phaeocystis sp. Alcian blue staining of colonies: (A) unstained colony, (B) colony stained at $\mathrm{pH} 2.5$, (C) colony stained at $\mathrm{pH} 0.5$. Scale bar $=50 \mu \mathrm{m}$
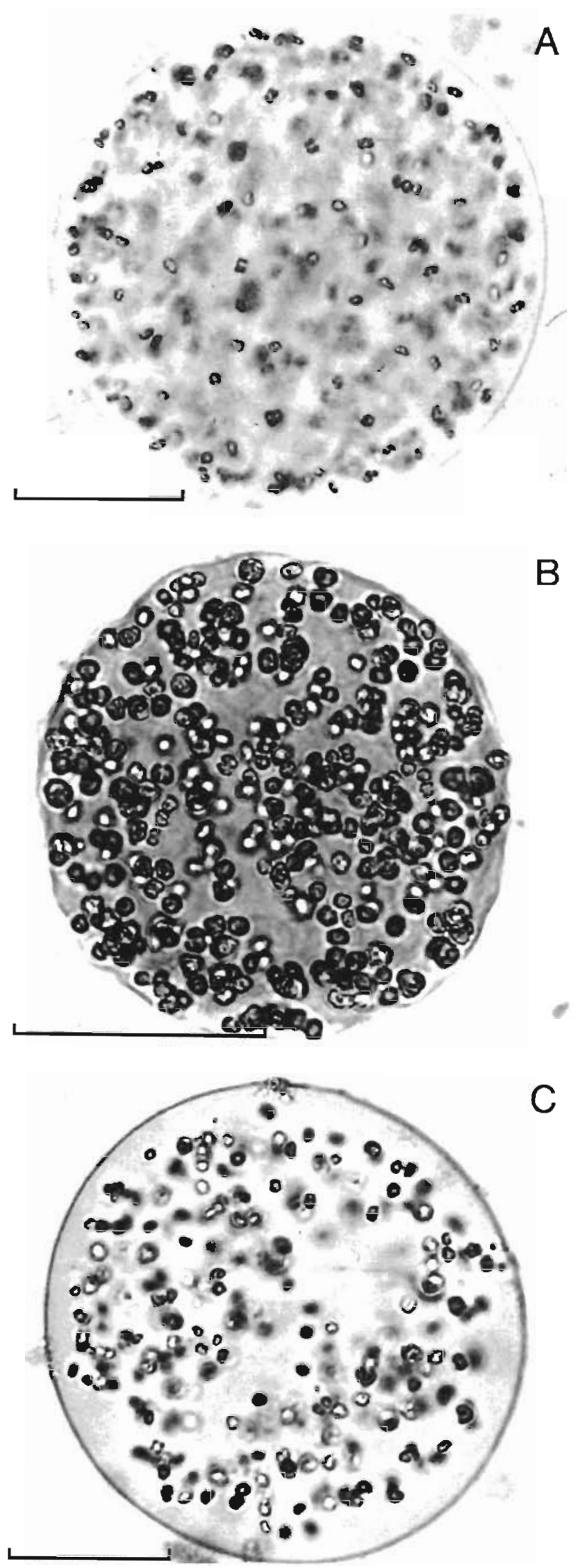
Table 1. Phaeocystis sp. Percentage colony cells and growth rate during the exponential phase in batch cultures with different calcium concentrations in the medium. -: no growth

\begin{tabular}{|ccc|}
\hline $\begin{array}{c}\text { Calcjum } \\
\text { conc. } \\
\left(\mathrm{mmol}^{-1}\right)\end{array}$ & $\begin{array}{c}\text { \% Colony } \\
\text { cells in } \\
\text { culture }\end{array}$ & $\begin{array}{c}\text { Growth } \\
\text { rate } \\
\left(\mathrm{d}^{-1}\right)\end{array}$ \\
\hline 0.175 & - & - \\
0.35 & 0 & 0.54 \\
1.25 & 0 & 0.57 \\
1.5 & 6 & 0.55 \\
1.75 & 17 & 0.48 \\
2.0 & 45 & 0.56 \\
2.5 & 71 & 0.51 \\
3.75 & 87 & 0.51 \\
5.0 & 86 & 0.56 \\
7.5 & 73 & 0.61 \\
\hline
\end{tabular}

Other bivalent cations may also be involved. Davidson \& Marchant (1987) and Lubbers et al. (1990) found accumulation of $\mathrm{Mn}$ in Phaeocystis colonies. Lubbers et al. (1990) explained this to be the result of high $\mathrm{pH}$ values inside the colony which led to precipitation of Mn. It is known, however, that heavy-metal ions bind very well with poly-anionic polymers (Smidsrod \& Christensen 1991). The observed Mn accumulation might thus also be explained as an effect of the mucus composition of Phaeocystis colonies.

The results of the batch cultures experiment suggest that at calcium concentrations below $2.5 \mathrm{mmol} \mathrm{l}^{-1}$ formation and growth of Phaeocystis colonies is hampered due to low gel firmness caused by calcium

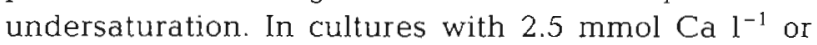
more gel firmness does not determine colony stability. In natural seawater the calcium concentration is ca $10.0 \mathrm{mmol} \mathrm{l}^{-1}$ (Kennish 1989). Evidently, in natural Phaeocystis colonies undersaturation of the calcium binding sites in the mucus will not occur easily.

Gel firmness of the mucus will also depend on its monomer composition. The ability to alter its mucus composition might be valuable to Phaeocystis. An increase in the amount of carboxylated and/or sulfated polymers in the mucus might yield a stronger gel that is more resistant to turbulence or penetration by predators. A weaker gel might be advantageous in situations where fast diffusion of nutrients inside the colony is preferable. Also, differences in Phaeocystis colony morphology, as found in the North Sea and Arctic waters (Baumann \& Jahnke 1986, Rick \& Aletsee 1989) and in Antarctic waters (A. Buma pers. comm.), may be the result of differences in colony mucus composition.

Acknowledgements. I thank $\mathrm{H}$. Huizing of ATO-DLO at Wageningen, The Netherlands, for useful suggestions and preliminary results of NMR analysis of Phaeocystis mucus, T
Keuning for practical assistance and $J$. Zagers for making the photographs. This work is a contribution to the EEC research project on the dynamics of Phaeocystis blooms in nutrientenriched coastal zones (Contract nr. EV4V-0102-B\{GDF\}).

\section{LITERATURE CITED}

Barnard, W. R., Andreae, M. O., Iverson, R. L. (1984). Dimethylsulfide and Phaeocystis poucheti in the southeastern Bering sea. Cont. Shelf Res. 3: 103-113

Bätje, M., Michaelis, H. (1986). Phaeocystis pouchetii blooms in the East Frisian coastal waters (German Bight, North Sea). Mar. Biol. 93: 21-27

Baumann, M. E. M., Jahnke, J. (1986). Marine Planktonalgen der Arktis. I. Die Haptophycee Phaeocystis pouchetii. Mikrokosmos 75: 262-265

Boney, A. D. (1981). Mucilage: the ubiquitous algal attribute. Br. phycol. J. 16: 115-132

Cadée, G. C., Hegeman, J. (1986). Seasonal and annual variation in Phaeocystis pouchetii (Haptophyceae) in the westernmost inlet of the Wadden Sea during the 1973 to 1985 period. Neth. J. Sea Res. 20: 29-36

Crayton, M. A. (1982). A comparative cytochemical study of volvocacean matrix polysaccharides. J. Phycol. 18: $336-344$

Davidson, A. T., Marchant, H. J. (1987). Binding of manganese by antarctic Phaeocystis pouchetii and the role of bacteria in its release. Mar. Biol. 95: 481-487

Decho, A. W. (1990). Microbial exopolymer secretions in ocean environments: their role(s) in food webs and marine processes. Oceanogr. mar. Biol. A. Rev. 28: 73-153

de Jong, E. W. (1975). Isolation and characterization of polysaccharides associated with coccoliths. Ph.D. thesis, University of Leiden, The Netherlands

Gibson, J. A. E., Garrick, R. C., Burton, H. R., McTaggart, A. R. (1990). Dimethylsulfide and the alga Phaeocystis pouchetii in antarctic coastal waters. Mar. Biol. 104: 339-346

Guillard, R. R. L., Hellebust, J. A. (1971). Growth and the production of extracellular substances by two strains of Phaeocystis poucheti. J. Phycol. 7: 330-338

Jahnke, J. (1989). The light and temperature dependence of growth rate and elemental composition of Phaeocystis globosa Scherffel and P. pouchetii (Har.) Lagerh. in batch cultures. Neth. J. Sea Res. 23: 15-21

Kennish, M. J. (1989). Practical handbook of marine science. CRC Press, Boca Raton

Kohn, R., Furda, I., Haug, A., Smidsred, O. (1968). Binding of calcium and potassium ions to some polyuronides and monouronates. Acta Chem. Scand. 22: 3098-3102

Lancelot, C., Billen, G., Barth, H. (1991). The dynamics of Phaeocystis blooms in nutrient enriched coastal zones. Water Poll. Res. Rep. 23, CEC Publication Series

Lancelot, C., Billen, G., Sournia, A., Weisse, T., Colijn, F., Veldhuis, M. J. W. Davies, A., Wassman, P. (1987). Phaeocystis blooms and nutrient enrichment in the continental coast zones of the North Sea. Ambio 16: 38-46

Lubbers, G. W., Gieskes, W. W. C., del Castilho, P., Salomons, W. Bril, J. (1990). Manganese accumulation in the high $\mathrm{pH}$ microenvironment of Phaeocystis sp. (Haptophyceae) colonies from the North Sea. Mar. Ecol. Prog. Ser. 59: $285-293$

Painter, T. J. (1983). Algäl polysaccharides. In: Aspinall, G. O. (ed.) The polysaccharides, Vol. 2. Academic Press, New York, p. 195-295

Palmisano, A. G., Soohoo, J. B., Soohoo, S. L., Kottmeier, S. T., 
Craft, L. L., Sullivan, C. W. (1986). Photo adaptation in Phaeocystis pouchetij advected beneath annual sea ice in McMurdo Sound, Antarctica. J. Plankton Res. 8: 891-906

Paul, J. H. (1982). Use of Hoechst dyes 33258 and 33342 for enumeration of attached and planktonic bacteria. Appl. environ. Microbiol. 44: 939-944

Ramus, J. (1977). Alcian blue: a quantitative aqueous assay for algal acid and sulfated polysaccharides. J. Phycol. 13: $345-348$

Rick, H.-J., Aletsee, L. (1989). The distribution of the haptophytes Phaeocystis pouchetii (Hariot) Lagerheim and Phaeocystis globosa (Scherffel) in the North Sea during May, June 1986 and February, March 1987. Meeresforsch. 32: $169-176$

Rouseau, V., Mathot, S., Lancelot, C. (1990). Calculating carbon biomass of Phaeocystis sp. from microscopic observations. Mar. Biol. 107: 305-314

Scott, J. E., Quintarelli, G., Dellovo, M. C. (1964). The

This note was submitted to the editor chemical and histochemical properties of Alcian Blue. I. The mechanism of Alcian Blue staining. Histochemie 4: $73-85$

Smidsrød, O., Christensen, B. E. (1991). Molecular structure and physical behaviour of seaweed colloids as compared with microbial polysaccharides. In: Guiry, M. D., Blunden, G. (eds.) Seaweed resources in Europe: uses and potentials. Wiley \& Sons, New York/Chicester, p. 185-217

van Boekel, W. H. M., Veldhuis, M. J. W. (1990). Regulation of alkaline phosphatase synthesis in Phaeocystis sp. Mar. Ecol. Prog. Ser, 61: 281-289

Veldhuis, M. J. W., Admiraal, W. (1987). The influence of phosphate depletion on the growth and colony formation of Phaeocystis pouchetii (Hariot) Lagerheim. Mar. Biol. 95: $47-54$

Wassmann, P., Vernet, M., Mitchell, B. G., Rey, F. (1990). Mass sedimentation of Phaeacystis pouchetii in the Barents Sea. Mar. Ecol. Prog. Ser. 66: 183-195

Manuscript first received: June 11, 1992

Revised version accepted: September 10, 1992 